\title{
Who's Peaked? Chris Kraus's Writing Performances as a Case Study for Twenty-First Century Writing Culture
}

\author{
Anneleen Masschelein
}

\begin{abstract}
:
In recent years, the work of Chris Kraus has crossed over from an avant-garde art circuit into mainstream literature. The self-reflexive stance and the strategies that she deploys to relate her own story to a broader intellectual and political context are reminiscent of certain tendencies in the Anglo-Saxon field of creative writing, but they mark her work first and foremost as an artistic research and performance. Kraus at the same time performs writing as an ongoing practice while revealing the writer as a simulacrum. In so doing, she formulates a strong critique of the male-dominated, capitalist worlds of art and theory at the end of the 2oth century but also offers a model for an alternative female subjectivity that is complex, fragmented, and fascinating.
\end{abstract}

\section{Anglo-Saxon Creative Writing in the Twenty-First Century}

Today, creative writing in the Anglo-Saxon world and increasingly in other parts of the world is a complex phenomenon best considered from the vantage point of three different realms: the university, popular writing culture, and the art world.

In general, the three domains can be related to distinct models of creative writing. MFA programmes in creative writing sponsor a range from high- to middlebrow fiction with a strong realist tendency, to more experimental postmodern writing.

The literary advice industry, by contrast, caters to a professional writing circuit associated with popular literature or genre fiction. Creative writing in this sense mostly focuses on specific genres that are considered lucrative, like romance, detective, or young adult fiction, and handbooks outline both the rules of the genre and the customs of the literary profession (how to approach an agent, address a publisher, etc.). A specific type of literary advice that came into being in the 1930s and today has developed into one of the most successful and respected subgenres is the combination of writing manual and self-help. In general, handbooks tend to have a bad reputation for being commercial for 
perpetually rehashing the same advice and mantras-'Write what you know,' 'Show, don't tell,' and 'Find your own voice.' Nevertheless, handbooks can help aspiring young writers, and particularly 'writer's memoirs' combining advice with information about a certain 'literary lifestyle' remain very popular today.

Most interesting in the context of artistic research is a third type of creative writing, which is fostered by the art world and can be captured as 'performative writing' embedded within interdisciplinary artistic practices. ${ }^{1}$ Today, more and more art schools are offering programmes in writing that not only entail writing about art (i.e. art criticism) but also writing as an artistic practice, often in combination with other media practices. ${ }^{2}$ Within this field, the influence of (French) Theory, that was huge in literary departments in the 1970s and 1980s, but much less in academic creative writing, cannot be underestimated. The enthusiastic reception by American visual artists, writers, performance artists, and filmmakers led to an interesting transformation of theory into a conceptual practice in the artistic sense.

In what follows, I want to explore one of the most remarkable cases of creative writing as artistic research: Chris Kraus, whose work is extraordinary for many reasons. First of all, as the editor of Semiotext(e), the leading publisher of (French) Theory until today, she played a crucial role in the introduction of French theory in the States, even though that role has not always been visible and remains under-examined. ${ }^{3}$ Secondly, starting out as a performance artist and experimental filmmaker, she turned to a form of auto-fictional writing that may seem confessional and voyeuristic at first sight, but that is, in fact, best understood as performance art within the medium of writing. Thirdly, in recent years, Kraus's work has achieved unexpected cult status for a vast audience, thanks to a shift in the position of her work that may be related to aspects of the three creative writing traditions outlined above.

1 Cf. Suze Adams, "Practice as Research: A Fine Arts Contextual Study," Arts and Humanities in Higher Education 13:3 (2014), pp. 218-226.

2 In Europe, creative writing as part of artistic research programmes is still in the very early stages, as Caduff points out, but in the Anglo-Saxon world, writing courses and workshops by and for artists have been offered in institutions like CalArts, Goldsmiths, the European Graduate School, to name but a few, since the 1990s, although not always in an institutionalised manner. Cf. Corina Caduff et al., eds, Art and Artistic Research, Zurich: Scheidegger \& Spiess, 2010.

3 For example, although Anaël Lejeune et al., eds., French Theory and American Art. Brussels: (SIC) and Berlin: Sternberg Press, 2013, pay a lot of attention to the role of Semiotext(e) and include a text by Lotringer, Kraus is not mentioned at all. 


\section{The 'Case' of Chris Kraus}

In the 2010s, the oeuvre of American author, editor, filmmaker, and performer Chris Kraus has been (re-)discovered, not just in the US but also in Europe. In the slipstream of re-editions and translations of Kraus's first novel I Love Dick (1997), and of an Amazon series made by Jill Soloway based on the novel and Kraus's persona (2016), the catchy title of that first book started appearing on T-shirts, tote bags, and Instagram. Meanwhile, Kraus is often cited as one of the defining authors of the millennium by writers and artists like Sheila Heti, Rachel Kushner, Rick Moody, Lena Dunham, McKenzie Wark, Carolee Schneeman, and Eileen Myles. In the UK, a first book devoted to her work consisted of essays and artistic interventions, including two videos and one recording, and resulted from a symposium devoted to Kraus's work hosted by the programme of Critical Writing on Art and Design at the Royal Academy of the Arts in London. ${ }^{4}$

Kraus's sudden rise to fame in her late fifties, early sixties is somewhat surprising. Sometimes perceived as narcissistic, navel-gazing, over-theoretical, and over-sexual, her first three auto-fictional novels, I love Dick, Aliens \& Anorexia (2000) and Torpor (2006) are painstaking recordings of her professional and romantic failures and a search for an identity as a "smart girl," "dumb Cunt," "hag" or "Kike" in the male-dominated, intertwined worlds of art and theory in New York and Los Angeles in the 1980s and 1990s. Quite remarkably, by now, Kraus almost seems to have overshadowed her former husband Sylvère Lotringer, the founder of the journal and publishing house Semiotext $(e)$, that she still runs with him and Hedi El Kholti. These days, she is definitely "peaking":

Who's Peaked? was a favorite guessing game among Jerome's new Berlin friends. (They also played it in London, New York and Paris.) Just as the Inuit had 33 words to describe different qualities of snow, Jerome and his friends enjoyed infinitely parsing different qualities of fame. Most of them agreed that fame was best arrived at through a slow and steady build. Global media-culture had produced an instant form of fame that was short-lived and arbitrary. Therefore, Jerome and all his friends agreed, it was much better for the artist to crossover from the underground in the mainstream culture after his third independent movie, her fourth one-person show. In this way, once the initial hype played out, there

4 Mira Mattar, ed., You Must Make your Death Public. A Collection of Texts and Media on the Work of Chris Kraus. London, Berlin: Mute Books, 2015. 
would still be hidden aspects of the biography and work for critics to discover. $^{5}$

Jerome Shafir, one of the protagonists in Torpor, Kraus's third novel about an intellectual couple that tries to save their failing marriage by halfheartedly attempting to adopt a child, bears a strong resemblance to Sylvère Lotringer, about whom we already learned a great deal from the previous two books. Likewise, Shafir's wife Sylvie Green can be regarded as an alter ego of Chris, the I-protagonist of the two first books. Since Kraus has said that she has no talent for making things up, ${ }^{6}$ one of the genre labels suggested for her work is "theoretical fiction." ${ }^{7}$ Kraus herself uses terms like 'Case Study,' 'Lonely Girl Phenomenology', and 'Project.' Moreover, from an artistic research perspective, her work can be perceived as an artistic project or performance. It brings together many different art forms and experiences, such as performance (she followed workshops with performance theorists Richard Schechner but also worked as a stripper), experimental film, French Theory, art criticism and teaching in art schools, and the New York literary scene of the 1980s and 1990s. She created a venue in the Semiotext $(e)$ series "Native Agents," which presents an extremely interesting selection of American poets, performers, and artists from various New York scenes, such as Cookie Mueller, Kathy Acker, David Rattray, Eileen Myles, David Wojnarowicz, and Bob Flanagan. ${ }^{8}$

Kraus herself emerged from Saint Mark's Poetry Project, the same scene as Patti Smith, although a decade later. ${ }^{9}$ Compared to the lyrical, romantic

5 Chris Kraus, Torpor (2006). London: Tuskar Rock Press, 2017, p. 154.

6 Rachel Cooke, “Novelist Chris Kraus: Who Hasn't Had an Affair?", in: The Guardian, 30 Apr. 2017, https://www.theguardian.com/books/2017/apr/30/chris-kraus-ive-never-had-much-talentfor-making-things-up-i-love-dick-interview, date of access: $17 \mathrm{Sept}$. 2018. At the same time, true to her autofictional stance, Kraus recently also called herself "such a fabulator." (The Revival of Chris Kraus and Her Radical Novel I Love Dick," in: Sleek, 5 May 2017, http://www .sleek-mag.com/2017/05/05/chris-kraus-interview-i-love-dick/, date of access: 17 Sept. 2018.)

7 Joan Hawkins, "Theoretical Fictions," in: Chris Kraus, I Love Dick. Los Angeles, CA: Semiotext(e), 2006, pp. 263-276.

8 For sources that document the history of the project from an inside perspective cf. Chris Kraus/ Sylvère Lotringer, "Introduction to the History of Semiotext(e)," in: Kraus/Lotringer, eds., Hatred of Capitalism. A Semiotext(e) Reader. Los Angeles, CA: Semiotext(e), 2001, pp. 13-24; Sylvère Lotringer, "My 8os. Better than Life," in: Artforum International 41 (2003), pp. 194-197 and pp. 252-253; Sylvère Lotringer, "American Beginnings," in: Lejeune et al., eds. (2013), French Theory, pp. 44-76; and David Morris, "Kraus Uncut. On Semiotext(e), Disclosure and Not-Knowing," in: Mattar, ed. (2015), Death Public, pp. 107-118.

9 In the 1980s, Kraus edited a performance series for Saint Marks. Cf. Miles Champion, "Insane Podium: A Short History. The Poetry Podium, 1966-2012," 2012, https://www.poetryproject .org/about/history/, date of access: 17 Sept. 2018. 
tone of Smith's bestselling memoir Just Kids, Kraus's account of the New York post-punk art world is extremely candid. ${ }^{10}$ In her work punk, art, theory, art criticism, and feminism are intertwined in a unique mixture. She blends sentimental, 'bourgeois,' and feminine genres like the epistolary novel, memoir, and coming-of-age story with a disenchanted, critical portrait of intellectuals in a period of global crisis and neoliberal triumph that remains recognisable today. Revolutionary philosophers, artists, and pop musicians are revealed to be hustlers, old school male-chauvinist dicks and not so wealthy, lonely, and unhappy people. Women especially, if they are not particularly beautiful and/ or young, but intelligent and quirky like Chris, remain caught up in poverty, exploitation, or invisibility, even at a time of feminism and Women's Liberation. From today's point of view, however, Kraus manages to offer a topical example for a new feminism in the still male-dominated art and media world. For despite the sense of failure, disenchantment, and despair, Kraus's novels are undeniably cool, funny, complex, fascinating, and impressive, as is Kraus herself.

\section{The Editor as Performance Artist}

At first sight, the overarching narrative in Kraus's first three books could be construed as one of 'finding her own voice,' one of the worn-out adagios of American style literary advice. In fact, it is perhaps more accurate to see it as a gradual shift from the invisible positions of editor and director to writer-protagonist-performer. The first book, I Love Dick, is an epistolary novel that starts as a joint 'project' by Kraus and Lotringer after 39-year-old Chris Kraus falls madly in love with theorist Dick Hebdige during a boozy dinner at his house. When she tells this to her husband, he proposes that the two of them each write letters to Dick in a kind of game, influenced by bourgeois literary examples like Pierre Choderlos de Laclos and Gustave Flaubert. However, for Kraus the letters are serious: she really loves Dick. More and more, she reconceives the project as a "case study," but not in the psychoanalytic sense of a study of female crisis or madness. As she points out in "Add it up"a long chapter in the form of a list, interspersed with stories and notes on

10 Patti Smith, Just Kids. New York, NY: Ecco, 2010. On Kraus's disenchanted portrait of New York, see McKenzie Wark, "Fur and Trembling," in: Chris Kraus, Torpor. London: Tuskar Rock Press, 2017, pp. 274-292. On the notion of 'candor' in the work of Kraus, see Karolin Meunier, "Speaking Candour," in: Mira Mattar, ed., You Must Make your Death Public. A Collection of Texts and Media on the Work of Chris Kraus. London, Berlin: Mute Books, 2015, pp. 75-86. 
schizophrenia - it is a more impersonal case that links her experiences to that of other women and a general cultural condition. In an introduction to the second edition of I Love Dick, poet Eileen Myles calls Kraus's case study "a philosophical achievement," as "she's turned female abjection inside out and aimed it at a man."11

Indeed, in the course of the book, the sense of failure and crisis that Chris experiences turns into a different kind of case, a court case or process, as is signalled by the frequent use of the header "Exhibit A, B, C...." All the letters, the recordings of phone calls and conversations, the diary entries are pieces of evidence (that in fact exist in the Semiotext $(e) \operatorname{archive}^{12}$ ). What they reveal, beyond the fact that things 'really' happened, is the meticulous build-up of an accusation, a complaint against the fact that, as Dick points out to Chris: "Men still do ruin women's life."13 That this realisation is not merely personal but structural is emphasised through the many other stories that are inserted in the narrative. There is, for example, Hannah Wilke, whose former partner Claes Oldenburg tried to literally remove her from his life and biography. And there is the solemn accusation of Richard Schechner, the performance theorist whose irresponsible behaviour as a workshop teacher verges on abuse.

In the second part of the book, "Every letter is a love letter," a shift occurs, and the dialogue with Sylvère through Dick turns into a diary form, in which Dick becomes DD, suggesting a coming of age of Chris as a writer and a possible happy romantic ending. Through the impersonal address of a diary needed as a stimulus to write, and through all the different tales and fragments, Chris (re-)discovers the use of the 'I,' her voice as a writer that was in fact there all along, long before she met either Sylvère or Dick.

It was as if I was right back there in this room in East $11^{\text {th }}$ Street, all those pages of notes that I was writing then, tiny ballpoint letters on wrinkly onion paper about George Elliot, diagrams of molecular movement and attraction, Ulrike Meinhof and Merleau-Ponty. I believed I was inventing a new genre and it was secret because there was nobody to tell it to. Lonely Girl phenomenology. ${ }^{14}$

11 Eileen Myles, "What About Chris?", in: Chris Kraus, I Love Dick. Los Angeles, CA: Semiotext(e), 2006, pp. 13-15: here p. 15.

12 David Morris, "Kraus Uncut. On Semiotext(e), Disclosure and Not-Knowing," in: Mira Mattar, ed., You Must Make your Death Public. A Collection of Texts and Media on the Work of Chris Kraus. London, Berlin: Mute Books, 2015, pp. 107-118: here p. 110.

13 Kraus (2006), I Love Dick, p. 172.

14 Kraus (2006), I Love Dick, p. 137. 
According to Hawkins, using the 'I' only works when Kraus learns to switch between different subject positions. ${ }^{15}$ Inserting increasingly long and substantial reflections on artists and artworks leads her to find a voice as an art critic and to establish a method for approaching art. This is based on a far-reaching form of identification with the subjects that she is talking about, such as Wilke, R. B. Kitaj, or David Rattray. ${ }^{16}$

Something similar happens in Aliens \& Anorexia, where the figures of Simone Weil and Paul Thek become living presences that fundamentally shape her artistic practice, most clearly the film Gravity and Grace (1996), named after Simone Weil's book, as well as her life. Moreover, at the end of the book, the film itself is described in a curious mixture of narrative and dramatisation that not just summarises it, but re-enacts it. In this way, the traditional practice of ekphrasis becomes a performance as well as a transition to fiction: if Gravity and Grace failed as a film, it is preserved in and as a story. Similarly, in Torpor, many descriptions of Sylvie Green's photographs can be found, as if in the catalogue for an imaginary exhibition, even though no images are included. ${ }^{17}$

A variation of this is found in I Love Dick, where Chris cites from her second, not yet existing book, Aliens \& Anorexia, but attributes the book to Dick. ${ }^{18}$ Thus, when Chris remarks: "You write about art so well," the statement is more complex than a compliment to her object of infatuation. It suggests a sense of self-love that the narrator-editor will discover belatedly that strongly contrasts with the low self-esteem that dominates the trilogy. Through Dick, Chris has discovered herself, both as a writer and as a lover. Not a lover in the sense of the romance novel, though, but in the Barthesian sense, as someone who performs the lover's figures, to the point of abjection. ${ }^{19}$ In so doing Kraus disturbs the gender roles inherent in the Western culture of love, and manages to take on another role that is usually associated with masculinity, that of the critic

15 Hawkins (2006), Theoretical Fictions, pp. 272-273.

16 This method is also deployed in Kraus's art criticism and in her most recent biography of Kathy Acker. See Linda Stupart, "Against Critical Distance: Chris Kraus and the Empathetic Exchange of Objects," in: Mira Mattar, ed., You Must Make your Death Public. A Collection of Texts and Media on the Work of Chris Kraus. London, Berlin: Mute Books, 2015, pp. 87-102.

17 In the new edition of Aliens \& Anorexia two stills from the movie can be found on the cover and the first page. See Chris Kraus, Aliens \& Anorexia (2000). Los Angeles, CA: Semiotext(e), 2013 .

18 Hawkins (2006), Theoretical Fictions, p. 272.

19 In A Lover's Discourse Roland Barthes famously listed a number of figures that capture the lover's behaviour, merging Western culture (opera, literature) with personal experience. Roland Barthes, A Lover's Discourse. Fragments, translated by Richard Howard. New York, NY: Hill and Wang, 2010. 
and artist, but explicitly as an amateur, a lover who understands art through empathy. When Kraus writes about art or herself, she reenacts and performs it in writing.

However, the story ends in a twist that undermines an all-too romantic happy end. In Los Angeles, Chris reconnects with Dick and has a brief fling with him, after which he turns out to be a 'real dick.' When Dick finally replies in writing, he does not even address Chris as a person. Instead, he writes a letter to Sylvère, in which he misspells her name, and simply sends her a copy, that is included in the book. ${ }^{20}$ The cruel negation of her as a human being, as a partner for dialogue, is mortifying but at the same time ridiculous, after the development and discoveries that have been made; and it once more confirms 'the case' that has been built up about the treatment of women in the art world.

As a result of the parataxical method of the narrator, ${ }^{21}$ all the stories, fragments, and scraps of evidence do not form a whole or lead to a happy end. There is no endpoint or final resolution in these stories, no lesson to be learnt or voice to be found. But like in a schizophrenic delirium, the oeuvre becomes alive as oeuvre: everything becomes meaningful and interlinked. In this sense, the long chapter on schizophrenia, "Add it up," does not explain Kraus's state of mind as a form of madness, but it explains her practice of art, thinking, and living. The writerly subject that is formed in the writing is a "schizo," who embraces the contradictions of capitalism and the impossibility to say 'I.' "(For years I tried to write but the compromises of my life made it impossible to inhabit a position. And 'who' am 'I'? Embracing you \& failure's changed all that 'cause now I know I am no one. And there's a lot to say ....."22 This subjectivity that Chris discovers to be "no one" is no longer negatively marked by failure or negation, but is a condition of possibility. It holds a potential for the future that has already been actualised at the moment of writing, and is presented through the intensely imaginative method that marks her art criticism and writing. Reviewing and editing her own life is a form of reenactment and play, not an analysis or reflection.

20 Kraus (2006), I Love Dick, pp. 258-26o.

21 In Torpor, Kraus explicitly discusses "parataxis" as "a strange literary form, born at the beginning of the Middle Ages," which, "flashing back and sideways", fractures "old familiar and heroic tales into contradictory, multiple perspectives” (Kraus, Torpor [2017], p. 70). In Kraus's own work parataxis serves as a way of saving fragments and a form of writing alternate histories (cf. Wark [2017], Fur and Trembling, pp. 281-282). Parataxis in Kraus can also be related to other artistic procedures, like collage and montage, as employed by Sophie Calle, for example. 


\section{Reframing the Writer as Simulacrum}

Commenting on the revival of I Love Dick, in 2017, Kraus remarks that because of the complex, contradictory strategies of her novel its "political aspects ... are overlooked in favour of its lifestyle aspects." ${ }^{23}$ These current interpretations are countered by the paratexts included in the new editions of the texts: long lists of praise for the books, prefaces by other writers, and interpretative essays after the texts, as well as cover photographs on the new editions of I Love Dick and Aliens \& Anorexia. With her long expertise as an editor, Kraus must be fully aware of the reframing effects. The cover photograph of I Love Dick, for instance, is a still life of an open notebook with pen, an ashtray, and a cup, half lit, half in the shadow. The photograph, "Treilles, 1996," was taken by Jean Baudrillard, one of Semiotext(e)'s star authors, famous for his theory of the logic of simulacrum in contemporary society. This representation of the paraphernalia of a contemporary writing culture-like other forms of late-capitalist popular culture-is marked by nostalgia for the analogue. However, combined with the name of Baudrillard as the photographer, it can also be read as a subtle hint that the traditional (male) writer is, in fact, a simulacrum. This interpretation is reinforced by Daniel Marlos's photograph on the back cover. It depicts Kraus, half hidden behind her hair, looking intently at two figurines, a bodybuilder in a vintage car (like the one Dick possesses in the book) and a woman in a wedding dress. Like an authorial narrator, Kraus looks down on her characters from above. The elements of play, manipulation, and self-irony captured in the authorial portrait undermine the truth-claims of the book as memoir. ${ }^{24}$

Together, the two photographs point to a dimension of Kraus's work that is particularly relevant today, not just in the context of artistic research but of writing culture in general: the notion of writing as a way of recording and shaping your experiences in an ongoing, serial work of art, as a stylisation of life. Rachel Sagner Buurma and Laura Heffernan refer to Roland Barthes's last course on the preparation of the novel, and they show how in a recent wave of "novels of commission" the impulse to write, the project of a novel, can itself become the subject of novels. ${ }^{25}$ These narratives take as their starting point the fact that a writer writes a book about writing a book. ${ }^{26}$ It hardly seems a

23 Revival of Chris Kraus (2017).

24 For a discussion of this photograph see Michelle Weidman, "Citizenship, the Body, and the Ethics of Exposure," in: Art Practical 8:1 (2016), http://www.artpractical.com/feature/ citizenship-the-body-and-the-ethics-of-exposure/, date of access: 17 Sept. 2018.

25 Rachel Sagner Buurma/Laura Heffernan, "Notation after The Reality Effect: Remaking Reference with Sheila Heti and Roland Barthes," in: Representations 125 (2014), pp. 80-102.

26 Examples of authors who have written novels of commission are Ben Lerner, Sheila Heti, Geoff Dyer, and Nell Stevens. 
coincidence that Sheila Heti, one of Buurma's and Heffernan's cases in point, provided the following blurb for Torpor:

I know there was a time before I read Chris Kraus's I Love Dick (in fact that time was only five years ago), but it's hard to imagine; some works of art do this to you. They tear down so many assumptions of what the form can handle (in this case, what the form of a novel can handle) that there is no way to recreate your mind before you encountered them.

In this quote, Heti captures the importance of Kraus's work as an artistic research in the field of creative writing. Departing from her story as a case study, or from mere auto-fiction, Kraus, in fact, transformed the form of the novel into something that cannot really be named but that profoundly changes what is possible in the field.

In Kraus's posture as it emerges in her work and persona, we thus see traces of different creative writing traditions converge. Although Kraus repeatedly emphasises that she is an autodidact, she did follow workshops (most notably that of Schechner), her work is highly self-reflexive, and she has taught artistic research at various institutions. Saint Marks and the New York art scene have shaped her writer-performer's stance. In her eclectic, voracious reading, she has also tended towards more popular, bourgeois genres, and the auto-fictional content of her work fits in with the memoir boom and the cultivation of a writerly lifestyle in popular culture. At the same time, a profound knowledge of French theory shapes her ironic, distanced, and critical stance. For Kraus, theory is a living tissue that connects everything, no matter how inconsistent, fragmentary, extremely personal, verging on gossip, or hybrid.

Having soaked up and absorbed all these influences, Kraus's position as writer can be regarded as a perfect simulacrum of the endlessly repeated rules of American creative writing culture: "Write what you know," "Show don't tell," and "Find your own voice." This simulacrum, from a specific feminine/queer position, functions as a complex 'schizo' machine against capitalism, patriarchy, and traditional literary genres and forms, as well as a unique art project that continues to fascinate new publics.

\section{Bibliography}

"The Revival of Chris Kraus and Her Radical Novel I Love Dick," in: Sleek, 5 May 2017, http://www.sleek-mag.com/2017/05/05/chris-kraus-interview-i-love-dick, date of access:17 Sept. 2018. 
Adams, Suze, "Practice as Research: A Fine Arts Contextual Study," in: Arts and $\mathrm{Hu}$ manities in Higher Education 13:3 (2014), pp. 218-226.

Barthes, Roland, A Lover's Discourse. Fragments, translated by Richard Howard. New York, NY: Hill and Wang, 2010.

Buurma, Rachel Sagner/Laura Heffernan, "Notation after 'The Reality Effect': Remaking Reference with Sheila Heti and Roland Barthes," in: Representations 125 (2014), pp. 80-102.

Caduff, Corina, et al., eds., Art and Artistic Research. Zurich: Scheidegger \& Spiess, 2010. Champion, Miles, "Insane Podium: A Short History. The Poetry Podium, 1966-2012," 2012, https://www.poetryproject.org/about/history/, date of access: 17 Sept. 2018.

Cooke, Rachel, “Novelist Chris Kraus: Who Hasn't Had an Affair?” The Guardian, 30 Apr. 2017, https://www.theguardian.com/books/2017/apr/30/chris-kraus-ive-neverhad-much-talent-for-making-things-up-i-love-dick-interview, date of access: 17 Sept. 2018.

Hawkins, Joan, "Theoretical Fictions," in: Chris Kraus, I Love Dick. Los Angeles, CA: Semiotext(e), 2006, pp. 263-276. [First published as "Smart Art and Theoretical Fictions," in: ctheory, 20 Feb. 2001, http://www.ctheory.net/articles.aspx?id=291, date of access: 17 Sept. 2018.]

Kraus, Chris, I Love Dick (1997). Los Angeles, CA: Semiotext(e), 2006.

Kraus, Chris, Aliens \& Anorexia (2000). Los Angeles, CA: Semiotext(e), 2013.

Kraus, Chris, Torpor. London: Tuskar Rock Press, 2017 [originally published Los Angeles, CA: Semiotext(e), 2006].

Kraus, Chris/Sylvère Lotringer, "Introduction to the History of Semiotext(e)," in: Kraus/Lotringer, eds., Hatred of Capitalism. A Semiotext(e) Reader. Los Angeles, CA: Semiotext(e), 2001, pp 13-24.

Lejeune, Anaël, et al., eds. French Theory and American Art. Brussels: (SIC), Berlin: Sternberg Press, 2013.

Lotringer, Sylvère, “My 80's. Better than Life," in: Artforum International 41 (2003), pp. 194-197 and pp. 252-253.

Lotringer, Sylvère, "American Beginnings," in: Anaël Lejeune et al., eds., French Theory and American Art. Brussels: (SIC) and Berlin: Sternberg Press, 2013, pp. 44-76.

Mattar, Mira, ed., You Must Make your Death Public. A Collection of Texts and Media on the Work of Chris Kraus. London, Berlin: Mute Books, 2015.

Meunier, Karolin, "Speaking Candour," in: Mira Mattar, ed., You Must Make your Death Public. A Collection of Texts and Media on the Work of Chris Kraus. London, Berlin: Mute Books, 2015, pp. 75-86.

Morris, David, "Kraus Uncut. On Semiotext(e), Disclosure and Not-Knowing," in: Mira Mattar, ed., You Must Make your Death Public. A Collection of Texts and Media on the Work of Chris Kraus. London, Berlin: Mute Books, 2015, pp. 107-118. 
Myles, Eileen, “What About Chris?", in: Chris Kraus, I Love Dick. Los Angeles, CA: Semiotext(e), 2006, pp. 13-15.

Smith, Patti, Just Kids. New York, NY: Ecco, 2010.

Stupart, Linda, "Against Critical Distance: Chris Kraus and the Empathetic Exchange of Objects," in: Mira Mattar, ed., You Must Make your Death Public. A Collection of Texts and Media on the Work of Chris Kraus. London, Berlin: Mute Books, 2015, pp. 87-102.

Wark, McKenzie, "Fur and Trembling," in: Chris Kraus, Torpor. London: Tuskar Rock Press, 2017, pp. 274-292.

Weidman, Michelle, "Citizenship, the Body, and the Ethics of Exposure," in: Art Practical 8:1 (2016), http://www.artpractical.com/feature/citizenship-the-body-and-theethics-of-exposure/, date of access: 17 Sept. 2018. 